\title{
THE DISCHARGE OF NEMATOCYSTS IN RELATION TO PROPERTIES OF THE CAPSULE
}

\author{
$\operatorname{AUTHOR}(\mathrm{S}):$ \\ Robson, Elaine A.
}

\section{CITATION:}

Robson, Elaine A.. THE DISCHARGE OF NEMATOCYSTS IN RELATION TO PROPERTIES OF THE CAPSULE. PUBLICATIONS OF THE SETO MARINE BIOLOGICAL LABORATORY 1973, 20: 653-673

ISSUE DATE:

1973-12-19

URL:

http://hdl.handle.net/2433/175752

RIGHT: 


\title{
THE DISCHARGE OF NEMATOCYSTS IN RELATION TO PROPERTIES OF THE CAPSULE
}

\author{
ElAINE A. ROBSON \\ Zoology Department, University of Reading, England
}

With 1 Text-figure and Plates $I-V$

\begin{abstract}
Introduction
Nematocysts are characteristic of the phylum Cnidaria and it is difficult to think of a species where they are not essential to the animal's habit of life. Cnidaria need their nematocysts, they use them and could not do without them. Nematocysts are thus a highly functional system and one may suppose that the evolution of at least some of their features has been influenced by natural selection. Cnidaria probably originated in pre-Cambrian times and the phylum has flourished ever since. Nobody has suggested, however, that the early coelenterates were without nematocysts, although at some stage in their evolution this presumably must have been so: it is commonly accepted that early Cnidaria used nematocysts much as present-day species, and we do not think of these characteristic elements as appearing suddenly, for example, during the Devonian era. Fossil forms recognized as Cnidaria are attributed nematocysts on the grounds that if ancestral species were carnivorous, cnidae then as now would represent the basic weapon of such carnivores against their prey.

Nematocysts of modern Cnidaria show great variety (WEILL, 1934). As this variety reflects mainly genetic characteristics, differences at species level can usually be discerned. In broader perspective, the distribution of types of nematocysts reflects the major taxonomic divisions of the phylum (WEILL, 1934; WERNER, 1965).

At the same time, because nematocysts are useful one might expect those found in particular species to show some adaptive features, perhaps in quality, range of size, or in distribution or mode of function. Most of the functional aspects of cnidae concern the animal's behaviour in some way, as they may be used to catch and kill prey, in defence or for adhesion to surfaces. If habit and physiological characteristics have indeed been influenced by natural selection might not such features as the way in which nematocysts are used, or their size or toxicity have been affected? Even so, general statements about adaptation in nematocysts are not easy to make, for they are after all cellular secretions and one is considering the cnidom, or rather its diverse cnidoblasts, as a physiological system. It is difficult, therefore, to use concepts which refer to whole organisms such as adaptive radiation. At a histological level, however,
\end{abstract}


one may still consider how the division of labour produces physiological efficiency. Nematocysts are undoubtedly efficient. In the case of Hydra the deadly poison of a few stenoteles dispatches the victim, already held by desmonemes coiled round its bristles like small adhesive springs. There are limits, of course, and if the crustacean is too large it escapes.

Several physiological questions follow. What stimuli excite or inhibit the discharge of nematocysts in living tissues? How do these stimuli operate? What happens during the discharge of a nematocyst? What kinds of features differ among cnidae with different functions? Again, many aspects of function in nematocysts would be clearer if we knew more about their development (see SlaUtTERBACK, 1963; WeSTFall, 1966; SKAER 1973). Differentiated but immature nematocysts do not discharge: which key features in the organization of the cnidoblast are as yet incomplete?

This account is concerned with the question "When do nematocysts discharge?", and it attempts to relate what happens in ordinary conditions to the structure of the nematocyst capsule and of the cnidoblast. It owes much to observations and ideas previously expressed by WeILL (1934) and YANAGITA (e.g. 1943, 1960), and to the work of Picken and Skaer (1966; and Picken, 1953; Skaer and Picken, 1965).

\section{Material and Methods}

The following material has been used: Corynactis viridis, and also Anemonia sulcata and Calliactis parasitica from Plymouth, England; Gonactinia prolifera from the Gullmarsfjord, Sweden; and formalin-fixed Rhodactis sanctithomae from Puerto Rico (through the kindness of Dr. C.E. CuTRESs). For electron microscopy specimens were anaesthetized for 15 minutes in equal volumes of seawater and $7 \frac{1}{2} \% \mathrm{MgCl}_{2} \cdot 6 \mathrm{H}_{2} \mathrm{O}$. They were fixed in gluteraldehyde for 2 hours following a method similar to that of GuPTA and LitTle (1969), usually with $10 \mathrm{mM} \mathrm{CaCl}_{2}$ added to the fixative. Specimens were cut up over wax while in gluteraldehyde. They were later washed in buffer, postfixed for 1 hour, dehydrated and embedded in araldite. Sections were stained with uranyl acetate and lead citrate (for methods see Grimstone and SKAER, 1971) and examined in a Hitachi HS-7S electron microscope.

\section{Changes in Volume of the Capsule}

When a nematocyst discharges the capsule itself commonly decreases in volume. Extensive evidence provided by WEILL (1934) confirmed the previous work of IWANZOFF (1896), WILL $(1909 a, b ; 1919)$ and others, and is supported by later observations (Yanagita, 1943; Jones, 1947; see Picken, 1953). The decrease in capsular volume may exceed $50 \%$, but as this decrease is often less than the volume occupied by the everted thread, in such cases the overall volume of the nematocyst must increase. Any change in volume of the capsule indicates that its wall is in some measure elastic. 
Most of the published measurements appear to concern isolated nematocysts or do not take into account the state of the surrounding tissues. This may, however, make an important difference to the size of undischarged nematocysts since when no longer protected by a cnidoblast they may swell. WeILL (1934) reported that using fragments of mesenteries from Corynactis and related Anthozoa he had seen holotrichous isorhizas enlarge momentarily, possibly doubling in volume, just before they discharged. PICKEN (1953) observed that these capsules became slightly plumper before discharge. It has now been confirmed that the holotrichous isorhizas of Corynactis swell considerably on exposure to sea water. After discharge, the capsules return to exactly their original dimensions (Figs. 3-7; Text-fig. 1).
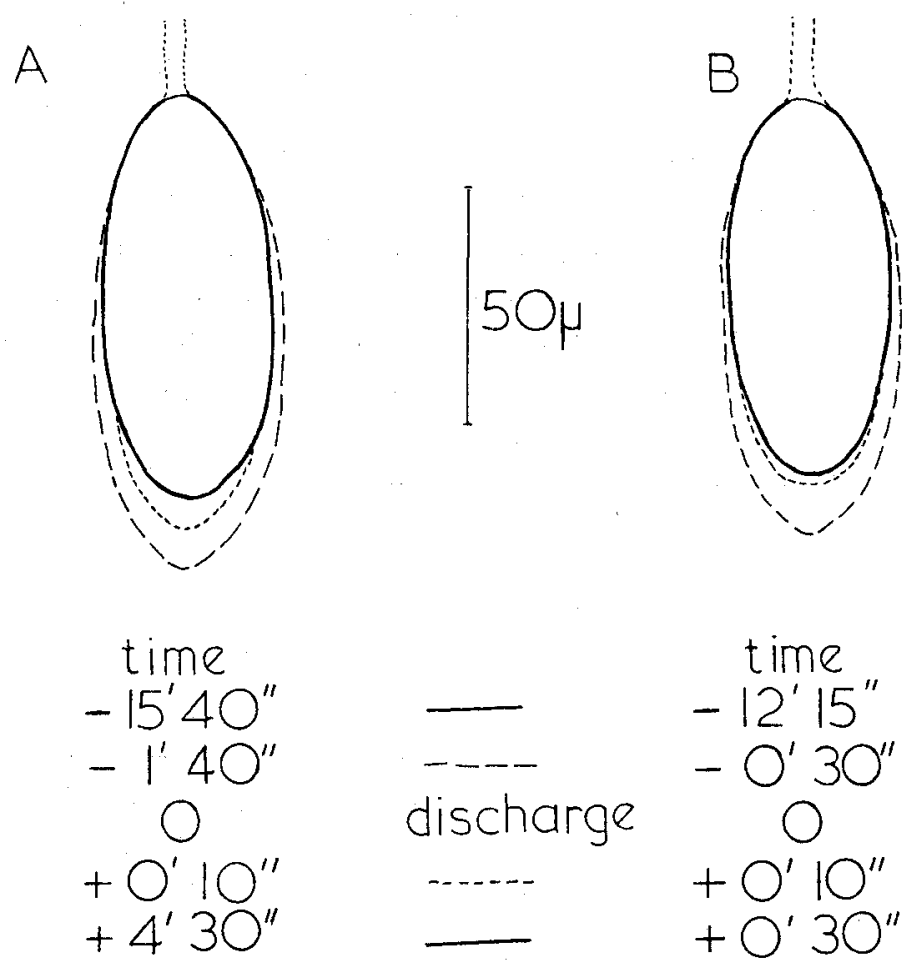

Text-fig. 1. Corynactis: capsules of two holotrichous isorhizas before and after discharge to show changes in volume. (A) represents the nematocyst in Figs. 3-7, (B) was adjacent. The preparation was a piece of mesenteric filament mounted in sea water.

These observations have been made using pieces of proximal mesenteric filament from Corynactis mounted in a small quantity of sea water and observed with dark ground illumination or phase contrast. Individual nematocysts have been watched for several minutes until they discharged (see Figs. 1, 2). Broadly speaking, so long as the covering cytoplasmic layer is visibly intact and the external medium has no 
access to the capsule, the size and appearance of undischarged nematocysts remain constant. As soon as the plasma membrane appears to deteriorate an undischarged capsule begins to swell. It may increase in volume to $150 \%$. At the same time the base of the tube protrudes as a growing bleb, while the opposite pole of the capsule becomes slightly pointed. These features suggest that the internal pressure has increased owing to uptake of water by the contents of the capsule, breaking the opercular seal, and that the base of the tube is forced outward. Nematocysts in sea water may remain in this state for some minutes. When discharge is imminent the nematocyst swells no further but local saccadic movements of the tube may be seen within the capsule while the bleb very slowly everts until, suddenly, the barbed portion of the thread is shot out (Figs. 2, 5). If the nematocyst is situated at the surface of the epithelium, particles in the external sea water often move towards the capsule, indicating a rapid inflow of water which may continue for some seconds after firing. Within the empty capsule other particles are drawn up the axis of the tube in the wake of the everting thread and they may reach the open tip, a distance of about $4 \mathrm{~mm}$. Unless they happen to be immediately opposite the base of the thread and are drawn into it, however, most of the intracapsular particles show only Brownian movement.

On firing, the nematocyst capsule decreases in volume as shown in Figs. 5-7 and Text-fig. 1: an immediate drop is followed by a slower return to previous resting dimensions, taking perhaps half a minute or more. These capsules undergo relatively little change in shape. Before discharge they increase in length by up to $15 \%$, which implies an increase in surface area of approximately one-third and in volume of onehalf. The fact that the capsule wall returns to exactly its resting profile after discharge of the thread supports the suggestions of earlier workers that it is elastic, but not that it is under tension in the resting state. It would appear, rather, that pressure within the capsule rises as water enters and the capsule is blown up like a balloon until the wall becomes maximally stretched. The opercular seal, which must be a mechanically weaker area, may be seen to break at an early stage and the base of the tube is slowly protruded owing to intracapsular pressure. Rapid devagination of the main part of the tube follows, it would appear, as soon as the portion bearing barbs is exposed to the external medium (Fig. 2).

The "stopper" mechanism described by YANAGITA (1943) is thus removed by hydrostatic pressure in these nematocysts. Sometimes, however, this fails to happen, and the barbed portion of the thread may then elongate while still in the capsule (PICKen, 1953; RoBson, 1953). If the capsular fluid is diluted by ingress of water but the capsule does not discharge there is enough room for the thread to elongate and it unwinds with characteristic jerks as the tube wall unfolds partly or completely (Figs. 8, 2).

These observations have been made in conditions where undischarged nematocysts swell slowly for several minutes before discharging but as seen by WEILL the capsule may also increase in size very rapidly and fire right away. Faster swelling would 
cause a sharper increase in internal pressure and immediate devagination. Compared to some nematocysts, the holotrichous isorhizas of Corynactis discharge relatively slowly: in tentacles, they fire off within 2 seconds of electrical stimulation (PICKEN and SKAER, 1966) and eversion may last for 2 or 3 seconds. With mesenteric filaments, present observations suggest that electrical stimuli may cause nematocysts to discharge after a much briefer latency, and furthermore they do not discharge unless they are also extruded from the cells. In $H y d r a$, stenoteles fire after a latent period of only 40-60 msec, and discharge takes only 3-6 msec to complete (REISINGER, 1937).

How nematocysts are excited in normal circumstances may be a question of how and where a sudden influx of water is brought about and further study is needed. One may ask how a stimulus might initiate swelling of the capsule and where water might enter. With regard to the latter question, the uniform texture of the capsule wall suggests uniform permeability, except perhaps for the area adjoining the base of the thread. The opercular seal presumably does not leak for once it has broken the capsule may swell quite fast.

\section{The Structure of the Capsule}

The structure of the capsule is related to its function as a pressure-resistant balloon with limited elastic properties.

Nematocysts are built of a disulphide-linked collagen (YANAGITA and WADA, 1954; YANAGITA, 1959; BlanqueT and LenHoFF, 1966; MARISCAL and LenHOFF, 1969), comparable perhaps to the cuticle of Ascaris (MCBRIDE and Harrington, 1967). Reagents which break disulphide bonds usually dissolve the empty capsule wall (apparently from within) and sometimes the discharged thread; spirocysts and undischarged nematocysts, however, are usually unaffected. The reversible increase in length of $15 \%$ observed in capsules from Corynactis (p. 656) would be consistent with the properties of vertebrate collagen fibres under tension, which may extend for 10-20\% without breaking (HARKNESS, 1968).

Electron microscope studies show that in most cnidae the capsule wall consists of two layers. At least in Anthozoa these layers are fibrous and in crossed helicoidal arrangement (Skaer and PiCken, 1965; WestFall, 1965; Doumenc, 1971).

In Rhodactis, holotrichous isorhizas are so large (WEILL, 1934) that the orientated structure of the capsule wall is seen with the light microscope. Figs. 11-13 show the two helicoidal layers: the outer fibres run counter-clockwise, at approximately $70^{\circ}$ to the axis of the capsule, the inner fibres clockwise (i.e. as barb-spirals on the discharged tube, see Fig. 2) at approximately $45^{\circ}$ to the axis. The angle between the two helices is probably within the range $110-120^{\circ}$. At least in the case of spirocysts the inner "fibres" are actually parallel folds or corrugations (Figs. 16, 25; SKAER and Picken, 1965). Formalin-fixed specimens can be crudely dissected using fine pins and the two layers then tear or peel away readily (Fig. 12). Both layers are birefringent 
(Fig. 13) but preliminary attempts to distinguish intrinsic and form birefringence have not been pursued as both are so weak. The overall birefringence of the capsule in Corynactis, negative with respect to its axis, is evidently composite in origin (PICKEN, 1953; Picken and Skaer, 1965).

In the smaller capsules of Corynactis an orientated fibrous wall structure is suggested by the light microscope but details are usually beyond resolution. In fresh preparations of holotrichous isorhizas, however, a few of the discharged capsules show unexplained diagonal markings running parallel to the everted barb-spirals, and hence to the inner folds of the capsule wall. Their appearance under dark ground illumination or phase contrast suggests indentations or short creases rather than slits, but their origin is not yet clear (Figs. 9, 10, 14). They are not seen before discharge.

The empty capsules of holotrichous isorhizas from Rhodactis and Corynactis are strikingly iridescent, owing possibly to the repeating structure of the inner wall.

In electron microscope sections the structure of the capsule wall is most readily discerned in spirocysts (see Figs. 21, 22). In Corynactis (Skatr and Picken, 1965) outer fibres, perhaps 250-300 $\mathrm{A}^{11}$ apart and finely striated, run obliquely over the regular parallel folds of the inner layer. These folds, about $350 \mathrm{~A}$ deep and $400 \mathrm{~A}$ apart, represent a continuous membrane, itself composed of fine parallel fibrils $40 \mathrm{~A}$ thick which run across the folds (here at $70-80^{\circ}$, but in general transversely). Spirocysts from other species show relatively little variation. In Metridium the inner folds are 440-480 A apart with striations at 110-115 A (WeSTFAll, 1965). In Actinia the inner folds repeat at $400 \mathrm{~A}$ while the outer fibres, making an angle of $120^{\circ}$ with them, are set $250 \mathrm{~A}$ apart (DOUMENC, 1971).

In holotrichous isorhizas of Corynactis the structure of the capsule wall seems essentially similar, and the inner layer shows comparable fine striations 99-107 A apart (SKAER and PICKEN, 1965).

Illustrations are given here from spirocysts of Gonactinia (Figs. 15-17). The wall of the capsule may be thought of as a balloon of elastic corrugated cardboard, whose helicoidal inner folds are bounded by a flat layer of outer fibres. These two helices are again set asymmetrically with respect to the axis of the capsule and the angle between them is $105-115^{\circ}$ (Fig. 15). The outer fibres are spaced regularly, perhaps 270-320 A apart, and although quite stout are under $150 \mathrm{~A}$ thick (Figs. 15, 17). The inner folds, about $440 \mathrm{~A}$ apart as in other species, are striated across their length at 100-115 A (Fig. 16). In transverse section double punctate rows suggest a fibrillar substructure (Fig. 15), a matter of interest in relation to the mechanical properties of the capsule (p. 656).

The folded layer lining the capsule is continuous with the thread (Figs. 25, 27 and the authors quoted above) and both show clockwise helical folds although those of the invaginated thread are, of course, of greater magnitude (SKAER and PICKEN, 1965).

1) $1 \mathrm{~A}=10^{-10} \mathrm{~m}=10^{-1} \mathrm{~nm}$ 
There is no obvious line of weakness where the thread joins the capsule, indeed the wall of the thread is thicker than the folded capsule lining. More information is needed about the structure of the thread. SKaER and PICKEN (1965) suggested that it might have a crossed fibrillar structure resembling that of the capsule, and this could account for the striking reversible extensibility of discharged threads. Present attempts to reveal the substructure of discharged threads of Rhodactis by tearing formalin-fixed material (p. 657), however, were inconclusive.

As noted, when the capsule wall accommodates an increase in volume to $150 \%$ or more, the collagenous fibres of which it is composed must be subjected to a tangential strain near their maximal capacity (p. 657). This would apply particularly to the outer single layer of fibres, since the inner folds would tend simply to straighten out as the wall was stretched. If the surface area of the capsule increases by one-third (p. 656) unfolding of the lining will be far from complete (Figs. 16, 25). Unless it turns out that the inner layer consists of subfibrils running parallel to the folds themselves, which is not at once evident from their transverse striation, this lining would appear to be under less tension than the outer fibres when the capsule swells. It seems possible to attribute the elastic properties of the capsule wall to the outer layer of fibres but such an interpretation needs further evidence.

As the structure and fibrous orientation of the capsule wall probably govern changes in its shape and volume it would be very interesting to study a variety of nematocysts from this point of view.

\section{The Cnidoblast: Endoplasmic Reticulum and Vacuoles}

How the discharge of nematocysts is normally controlled in Anthozoa is a problem of considerable interest. A few observations on cnidoblasts from tentacles of Gonactinia may have some bearing on the question. Material for electron microscopy was fixed in gluteraldehyde after anaesthetizing with magnesium chloride (p. 654), and while artifacts of preparation are evident the features under consideration have been seen also in tentacles of Corynactis and Anemonia. The cnidoblasts of Anthozoa have no cnidocils, and although a cilium is usually associated with nematocysts even this is lacking when spirocysts are concerned (WESTFALL, 1965; DoumenC, 1971). As the discharge of a spirocyst cannot depend on the excitation of a receptor cilium, do other features of the cell throw light on its functions as a combined receptor-effector?

It may be relevant that the capsule, at least in spirocysts, appears to be invested by a branching tubular reticulum (Figs. 15-19, 26). The tubules show a single unit membrane and may be only $150 \mathrm{~A}$ wide. They adhere to the capsule wall and are especially obvious in this material because the spirocysts are often flanked by a lateral space or vacuole (Figs. 23, 24). Although such a space may be artificial it can be seen in living material in some conditions (Figs. 21, 22). It could perhaps be concluded that these cnidoblasts easily develop large vacuoles. The pericapsular spaces described 
by YANAGITA and WADA (1959) round nematocysts in acontia of Diadumene appear to be similar.

Cnidae are secreted by the endoplasmic reticulum and during development the capsule lies within an unbroken cytoplasmic membrane (see SLAUTTERBACK, 1961, 1963; WeSTFALL, 1966). In spirocysts, this membrane is always evident over the distal apex, below the plasma membrane (Figs. 25, 27, 28). In this material, however, the proximal part of mature spirocyst capsules usually lacks the continuous membrane present at an earlier stage, and the tubular reticulum seems to be in contact with the capsule wall (Figs. 15-19, 24, 26). In some sections, usually distal, reticular tubules appear to join the nematocyst membrane (Fig. 20), while in others they are within adjacent cytoplasm and discrete. There is at first sight no evidence that this is because the nematocyst membrane has become transformed to a reticulum. In sections towards the base of the spirocyst small clusters of tubules usually cross the adjacent space to the periphery of the cell (Fig. 19).

This tubular reticulum could most plausibly be derived from the endoplasmic reticulum which at an earlier stage secretes the capsule and perhaps some of its contents. While attempts to interpret its function must be speculative, might it not assume a role comparable to that of sarcoplasmic reticulum in muscle? Could such a system perhaps control the ionic environment outside the capsule? In cnidoblasts a special means of regulating the ionic content might be appropriate in two respects. During the latter stages of development a nematocyst undergoes considerable dehydration, which would be correlated with invagination and buckling of the thread (SLautTERBACK, 1963; SKAER and PICKen, 1965). If withdrawal of water by some form of ion transport were postulated, it might not unreasonably involve a special part of the endoplasmic reticulum such as the structures reported here. Such a tubular reticulum is present round immature spirocysts by the stage at which an invaginated thread can be discerned.

A second possibility follows the suggestion of YANAGITA (see 1960) and others that the discharge of a nematocyst normally follows increased permeability of the cnidoblast, effective stimuli provoking discharge by causing ions and water to enter the cytoplasm. It would not seem impossible for channels of endoplasmic reticulum to sequester and release ions in a way which might affect the volume of water on contiguous cytoplasmic vacuoles, although how such a system might be influenced by external stimuli remains to be seen. In the case of spirocysts the large accompanying vacuoles might facilitate either their extrusion or perhaps the entry of fluid into the capsule. That these capsules are thin-walled and readily permeable, and their fluid contents of low viscosity (WeILL, 1934), may be related to the fact that the discharge of spirocysts is very rapid, taking only about $10 \mathrm{msec}$ in Corynactis (PICKEN and SkAeR, 1966).

The exact distribution of the tubular reticulum is not yet clear, especially in relation to the surface of the cell and to the various spaces which look like cytoplasmic vacuoles. At the apex of the spirocyst a thin disc of opercular material seals the 
attachment of the thread (Figs. 24, 25, 27; SKAER and PiCKen, 1965; Westrall, 1965; Doumenc, 1971). There is also a thin crown of arched supporting rodlets, possibly held by a ring of fibrous material, which encircles the top of the spirocyst (Figs. 24, $25,27)$. Just below the rodlets the capsule may be surrounded by membrane-bound vacuoles or sacs which are probably balloons of endoplasmic reticulum (Fig. 28; also 25,27 ). Some membrane-bound diverticula reach towards the surface of the cell, but no special areas of contact with the plasma membrane have yet been seen. It is tentatively suggested, however, that the membrane-bound vacuoles and tubular reticulum in these cnidoblasts are functionally related and may possibly be concerned in the initiation of discharge.

\section{Discussion}

Several types of physiological mechanism have been adduced to explain how the discharge of cnidae might be controlled (WEILL, 1934; JonES, 1947). Explanations must allow for a very short latency between stimulus and response: in freshwater Hydra the penetrants discharge only 40-60 msec after electrical stimulation (p. 657). As chemical removal of the opercular seal seems out of the question in the time available it is more probable that discharge is initiated by some rapid mechanical change. The contraction of cytoplasmic fibrils was long ago suggested as a fast means of increasing intracapsular pressure (CHUN, 1881), but at least in the case of spirocysts no such fibrils have yet been seen. Alternatively, discharge may be governed by entry of water into the capsule, a subsequent rise in pressure breaking the opercular seal (see p. 656). Observations on holotrichous isorhizas of Corynactis (Figs. 3-7) suggest that these capsules may not be under tension in the resting state: that is to say, a stimulus to the cell might trigger the beginning of a swelling-up process rather than its completion (but see YANAGITA, 1943).

There might follow two possibilities: either the permeability of the capsule wall itself is suddenly altered, or the environment of the capsule, which is normally controlled by the cell, changes drastically after stimuli. Bearing the normal speed of response in mind it is difficult to imagine in the first case what agent could influence the permeability of a disulphide-linked collagenous structure so quickly. The tensile properties of collagen are affected by their ionic environment (see HARKNESS, 1968), besides which the possible influence of a non-collagenous matrix on the mechanical properties of the capsule wall should not be overlooked (GosLINE, 1970a, $b$ ): but modifications of the capsule wall by a specific chemical agent within a fraction of a second does not at present seem to be the simplest hypothesis.

Possibly a simpler explanation is that cnidae take up water owing to a change in permeability of the cell or perhaps to rupture of the cell membrane. The osmotic pressure of capsular contents is extremely high [equivalent to 140 atmospheres in the holotrichous isorhizas of Corynactis (PICKEN and SKAER, 1966)] and it has long been 
suggested that capsules may act as osmometers (GLASER and Sparrow, 1909; Jones, 1947; Picken and Skaer, 1966). As it withstands dehydration in alcohol the osmotically-active material is probably not a protein but its nature has not yet been established (WeILL, 1934). In some conditions the capsule may be permeable to osmotically-active molecules. With isolated nematocysts of Metridium, GLASER and SPARROW (1909) found that hypertonic media prevented discharge, but after some time specimens would discharge if they were transferred to a weaker medium which was ordinarily too concentrated for them to do so. Some "slow osmotic interchange" is suggested by WILL's later observations on Hydra (1919). Having recorded the usual decrease in volume of capsules on firing, he also found some which had remained undischarged for 24 hours and which had decreased in volume by the same amount.

Although as observed by WeILL the uptake of water by an undischarged capsule may be very rapid it may also be slow, so that several minutes may elapse before discharge occurs (Figs. 4-6): this is usually the case when holotrichous isorhizas of Corynactis are exposed to sea water by extrusion or by cytolysis of the tissues. On the other hand, electrical stimuli which excite discharge also provoke extrusion. What is then the sequence of events? Does the plasma membrane of the cnidoblast rupture when the nematocyst discharges, or before? It would seem important to examine this with contact chemical stimuli which might occur naturally (see Pantin, 1942). While it is clear that normal, short-latency responses are mediated by cnidoblasts behaving as receptor-effector elements, exactly how they achieve this dual function cannot yet be described in detail. As a tentative guess it is suggested that if the endoplasmic reticulum in part controls the ionic milieu of the cell it may be able to respond to depolarization of the cell membrane. Such an interpretation would allow for other physiological features important in relation to behaviour, such as maturation of the response, and the influence of neural or epithelial excitation of the threshold of discharge.

Although cnidoblasts must have basic physiological properties in common, some variety in functional features might nevertheless be expected under the influence of natural selection. It is well known, for example, that the toxic contents of different nematocysts are not all the same, and that there are other chemical differences in composition between, say, spirocysts and nematocysts (p. 657). Receptor cilia, which tend to be unspecialized among Anthozoa, have diversified in other coelenterates. Among Hydrozoa, for example, there exists a spectrum of cnidocils. Could their variety offer a means whereby nematocysts with different functions are able to respond to slightly different stimuli? Unless the functional details of cnidoblasts have been particularly immune from evolutionary change, one might almost begin to ask which of the physiological characters of the cnidom have best lent themselves to speciation.

\section{Summary}

1. When exposed to sea water, undischarged holotrichous isorhizas of Corynactis 
increase in volume up to $150 \%$. After discharge the capsule returns to its previous dimensions. The capsule wall, known to be collagenous, is about as elastic as vertebrate tendon. It is inferred that intracapsular pressure rises before discharge.

2. As in other material the capsule wall consists of two fibrous layers arranged helicoidally, which would account satisfactorily for its mechanical properties.

3. In electron microscope sections of spirocysts from Gonactinia a tubular reticulum invests the capsule. It is suggested that this reticulum might be concerned in controlling the ionic contents of the cell and that it functions together with spaces or vacuoles which surround the spirocyst in this material. Such a system might be influenced by depolarization of the cell membrane, providing a link between stimulus and discharge, but further observations are needed.

\section{Acknowledgements}

It is a pleasure to acknowledge help from Dr. C. E. Cutress, Dr. A. Forer, Dr. B. L. Gupta, and from colleagues at Kristinebergs Zoological Station, Sweden and at the Laboratory of the Marine Biological Association, Plymouth. I am indebted to the E. M. Musgrave Fund, the Science Research Council and the Research Board of the University of Reading for financial support.

\section{REFERENCES}

Blanquet, R. \& Lenhoff, H. M., 1966. A disulphide-linked collagenous protein of nematocyst capsules. Science, 154 : 152-3.

Chun, C., 1881. Die Natur und Wirkungsweise der Nesselzellen bei Coelenteraten. Zool. Anz., 4: 646-50.

Doumenc, D., 1971. Aspects morphologiques de la dévagination du spirocyste chez Actinia equina L. J. Microsc., $12:$ 263-70.

Glaser, O. C. \& Sparrow, C. M., 1909. The physiology of nematocysts. J. exp. Zool., 6: 361-82.

Gostine, J. M., 1971. Connective tissue mechanics of Metridium senile.

a. I. Structural and compositional aspects. J. exp. Biol., 55: 763-74.

b. II. Viscoelastic properties and macromolecular model. Ibid., 775-96.

Grimstone, A. V. \& Skaer, R. J., 1971. A Guidebook to Microscopical Methods. Cambridge: University Press.

Gupta, B. L. \& Little, C., 1969. Studies on Pogonophora. II. Ultrastructure of the tentacular crown of Siphonobrachia. J. mar. Biol. Assoc., 49 : 717-41.

Harkness, R. D., 1968. Mechanical properties of collagenous tissue. In B. S. Gould (ed.) Treatise on Collagen, vol. 2, pp. 247-310. New York: Academic Press.

Iwanzoff, N., 1896. Ueber den Bau, die Wirkungsweise und die Entwicklung der Nesselkapseln der Coelenteraten. Bull. Soc. Imp. Nat. Moscou, N. S., 10: 95-161; 323-54.

JONES, C. S., 1947. The control and discharge of nematocysts in Hydra. J. exp. Zool., 105: $25-60$.

Mariscal, R. N. \& LenHofF, H. M., 1969. Effect of a disulphide reducing agent on coelenterate nematocyst capsules. Experientia, 25: 330-1.

McBride, O. W. \& Harrington, W. F., 1967. Ascaris cuticle collagen: on the disulphide crosslinkages and the molecular properties of the subunits. Biochem., 6: 1484-98.

Pantin, C. F. A., 1942. The excitation of nematocysts. J. exp. Biol., 19: 294-310.

Picken, L. E. R., 1953. A note on the nematocysts of Corynactis viridis. Quart. J. micr. Sci., 94: 203-27. 
Picken, L. E. R. \& Skaer, R. J., 1966. A review of researches on nematocysts. Symp. Zool. Soc. Lond., 16 19-50.

Rersinger, E., 1937. Der Entladungsvorgang der Nesselkapseln. Zool. Anz., Suppl. 10: 311-5.

Robson, E. A., 1953. Nematocysts of Corynactis: the activity of the filament during discharge. Quart. J. micr. Sci., 94: 229-35.

SkaER, R. J., 1973. The secretion and development of nematocysts in a siphonophore. J. Cell Sci., 13, 371-94.

SkaER, R. J. \& Picken, L. E. R., 1965. The structure of the nematocyst thread and the geometry of discharge in Corynactis viridis Allman. Phil. Trans. B, 250: 131-64.

Slautterback, D. M., 1961. Nematocyst development. In H. M. Lenhoff and W. F. Loomis (eds.) The Biology of Hydra, pp. 77-130. Florida: University of Miami Press.

Slautterback, D. M., 1963. Cytoplasmic microtubulues. I. Hydra. J. Cell Biol., 18: 367-88.

WeIll, R., 1934. Contribution à l'étude des cnidaires et de leurs nématocystes. Trav. Stn. zool. Wimereux, 10, 11 (I, II).

Werner, B., 1965. Die Nesselkapseln der Cnidaria, mit besonderer Berücksichtigung der Hydroida. I. Klassifikation und Bedeutung für die Systematik und Evolution. Helgol. Wiss. Meeresunters., 12: 1-39.

Westfall, J., 1965. Nematocysts of the sea anemone Metridium. Am. Zool., 5: 377-93.

Westfall, J., 1966. The differentiation of nematocysts and associated structures in the Cnidaria. $Z$. Zellforsch., 75: 381-403.

WiLL, L., 1909a. Ueber das Vorkommen kontraktiler Elemente in den Nesselzellen der Coelenteraten. Sitzb. Abhdln. naturf. Ges. Rostock, N. F. 1, 33-52.

WILL, L. 1909b. Die Klebkapseln der Aktinien und der Mechanismus ihrer Entladung. Ibid., 65-103.

WILL, L., 1919. Die Volumenreduktion der Nesselkapseln bei der Explosion und infolge "Alterns". Anat. Hefte, $57: 485-546$.

Yanagita, T. M., 1943. Discharge of nematocysts. J. Fac. Sci., Tokyo Univ., (IV), 6: 97-108.

Yanagita, T. M., 1959. Physiological mechanisms of nematocyst responses in sea anemone. I. Effects of trypsin and thioglycollate upon the isolated nematocysts. Jap. J. Zool., 12: 361-75.

Yanagita, T. M., 1960. Physiological mechanisms of nematocyst responses in sea anemone. VII. Extrusion of resting cnidae-its nature and possible bearing on the normal nettling response. $J$. exp. Biol., 36: 478-94.

YanAGITA, T. M. \& WADA, T., 1954. Effects of trypsin and thioglycollate upon the nematocysts of the sea anemone. Nature, 173: 171.

Yanagita, T. M. \& WAdA, T., 1959. Physiological mechanism of nematocyst responses in sea anemone. VI. A note on the microscopical structure of acontium, with special reference to the situation of cnidae within its surface. Cytologia, 24: 81-97.

\section{DISCUSSION}

WEILL: I want to congratulate you, Dr. RoBSon, and to express my sincere admiration, for your excellent work and particularly for your photographs, which are magnificent indeed. I have no objection to raise against your conclusions, except the third: I cannot agree that spirocysts are a particular kind of nematocysts. They are fundamentally different in two ways. Not because they are lacking a cnidocil; this is the case also for many kinds of nematocysts, in different species and locations. But in no spirocyst you can stain the fluid capsular content, that is easily stained in all nematocysts. Besides, the actual process of the thread-extension has never been observed in spirocysts, and I definitely doubt that such a discharge actually occurs in spirocysts, although smears easily show what could be taken to be stages of this discharge. I endeavoured for years to see spirocysts in the process of discharging, and I never succeeded, inspite of a variety of methods. Did you ever see a spirocyst discharge? 


\section{Robson: No, I did not.}

WeRNer: What about the function of the spirocyst? For general observations and conclusions, the more normal nematocysts should be used, as spirocysts are of a very specialized type. With regard to function, they are very often observed in the thin mucus sheet enclosing the soft body.

Robson: Spirocysts are adhesive. Those of the tentacles in Gonactinia are used to entangle crustacean prey, and to attach tentacles to the substrate during walking. In Ceriantharia especially, numerous spirocysts form part of the protective external tube. Even if spirocysts are specialized, their cnidoblasts show a relatively simple structure. For this reason it is interesting to seek here the minimal expression of physiological properties relating to discharge of cnidae.

MACKIE: At what stage in its development can a nematocyst first discharge? Does this coincide with the appearance of any ultrastructural specializations?

RobSON: After secretion of the nematocyst itself (see Slautterback, 1963; Westfall, 1966; SKAER, 1973) the cnidoblast may still have to mature in some way before the normal excitation of discharge becomes possible. It should be possible to find ultrastructural correlates of this maturation process. 


\section{EXPLANATION OF PLATES I-V}

PLATE I. Corynactis, holotrichous isorhizas seen with dark ground illumination.

Fig. 1. Edge of a mesenteric filament to show nematocysts in situ. $\quad$ Bar $=50 \mu$.

Fig. 2. Right, capsule before discharge. Centre, partly-discharged arrested nematocyst to show right-hand spirals of barbs on discharged thread; the uneverted thread within it has also unfolded, note its separated barbs. Left, tip of another arrested thread: here the uneverted portion still has closely-packed barbs. Bar $=10 \mu$.

Figs. 3-7. The same nematocyst before and after discharge to show changes in volume of the capsule, from a piece of mesenteric filament mounted in sea water. Bar $=10 \mu$.

3. Tissues intact (18'10" before discharge), capsule at resting size.

4. Cytoplasmic covering broken and capsule beginning to enlarge (10' $40^{\prime \prime}$ ' before discharge).

5. Capsule probably at maximum size, with base of tube everted (1'40" before discharge).

6. Capsule 10" after discharge.

7. Capsule 1'20" after discharge, dimensions as in Fig. 3.

Fig. 8. Nematocyst whose discharge was arrested with most of the thread still unerverted. Parts of the thread still in the capsule have unfolded, suggesting entry of water. Bar $=10 \mu$.

Figs. 9, 10. Discharged capsule showing unexplained marks or folds, thread towards top of page: focus on lower and upper surfaces of same capsule suggests clockwise spiral pattern. $B a r=10 \mu$.

PLATE II. Holotrichous isorhizas. $\mathrm{Bar}=10 \mu$.

Fig. 11. Rhodactis: formalin-fixed specimen in distilled water, phase contrast. Focus on one surface of the capsule wall shows something of the crossed helicoidal strueture.

Fig. 12. Rhodactis: a discharged capsule dissected with pins. The arrow shows a spiral tear at the apex (parallel to inner folds of capsule wall).

Fig. 13. Rhodactis: birefringence of another formalin-fixed empty capsule in distilled water. After tearing with pins, frayed inner and outer layers of the capsule wall both show weak positive birefringence. Capsule orientated as in Fig. 11, outer fibres bright, maximum extinction of inner layer.

Fig. 14. Corynactis: capsule showing markings as in Figs. 9 and 10, phase contrast. Marks are aligned as inner folds of the wall but in this flattened capsule those on both upper and lower surfaces are in focus.

PLATE III. Gonactinia, spirocysts in section. Bar $=0,1 \mu$.

Fig. 15. Glancing section of capsule wall, long axis of capsule horizontal. Note especially the investing tubular reticulum (r) and oriented structure of the capsule. Outer fibres (o) cross inner folds (i) at about $110^{\circ}$. At right, double lines of dots represent sectioned fibrils of the inner folds.

Fig. 16. Inner folds of capsule wall seen in oblique transverse section. Outer fibres do not show clearly, but adjacent reticulum can be seen.

Fig. 17. Another capsule: showing reticulum, layer of outer fibres in approximate transverse section, folds of inner layer seen tangentially, with vertical striations.

Fig. 18. The same capsule, to show tubular profile of the reticulum.

Fig. 19. A clump of tubules leading from the wall of a sectioned capsule across the surrounding space.

Fig. 20. In this section the capsule wall is invested by its membrane, but tubules which cross the adjacent space are continuous with it. 


\section{PLATE IV. Spirocysts.}

Fig. 21. Calliactis: spirocysts from a tentacle mounted in sea water with weak neutral red, to show vacuolar appearance of cnidoblast. Bent specimen is a late developing stage. Bar $=5 \mu$.

Fig. 22. Same preparation, similar spirocysts at the surface of the tentacle. $\operatorname{Bar}=5 \mu$.

Fig. 23. Gonactinia: approximately longitudinal section of tentacle, showing spirocysts near the tip. $\operatorname{Bar}=1 \mu$.

Fig. 24. The same tentacle, another spirocyst in longitudinal section (not median) to show the extent of spaces round the capsule, and the membranous/reticular investment of the capsule wall. There are supporting rods near the apex. $B a r=1 \mu$.

\section{PLATE V. Gonactinia, spirocysts. Bar $=1 \mu$.}

Fig. 25. Apex in longitudinal section (not median) to show membrane-bound vacuoles near the surface of the cnidoblast. Note how the thread wall is continuous with the inner folds of the capsule wall, and this area covered by opercular material. The apex is covered by both spirocyst membrane and plasma membrane.

Fig. 26. Oblique section, probably of the lower region of a spirocyst since reticular tubules surround the capsule instead of a continuous membrane.

Fig. 27. Longitudinal section (not median), just showing attachment of the thread in the opercular region. Note adjacent apical vacuoles and part of the circlet of supporting rods.

Fig. 28. An approximately transverse section near the apex to show the extent of surrounding vacuoles (probably at level of $v$ in Fig. 27). The spirocyst membrane outlines the capsule wall, and some of the apical supporting rodlets have been sectioned.

ABBREVIATIONS

$\begin{array}{ll}\mathrm{i}, \text { inner folds } & \mathrm{o}, \text { outer fibres } \\ \mathrm{m}, \text { membrane of spirocyst } & \mathrm{r} \text {, tubular reticulum } \\ \mathrm{s}, \text { supporting rodlets } & \mathrm{t}, \text { thread } \\ \mathrm{v}, \text { vacuole } & \end{array}$


Proc. Second Internat. Symp. Cnidaria

PLATE I
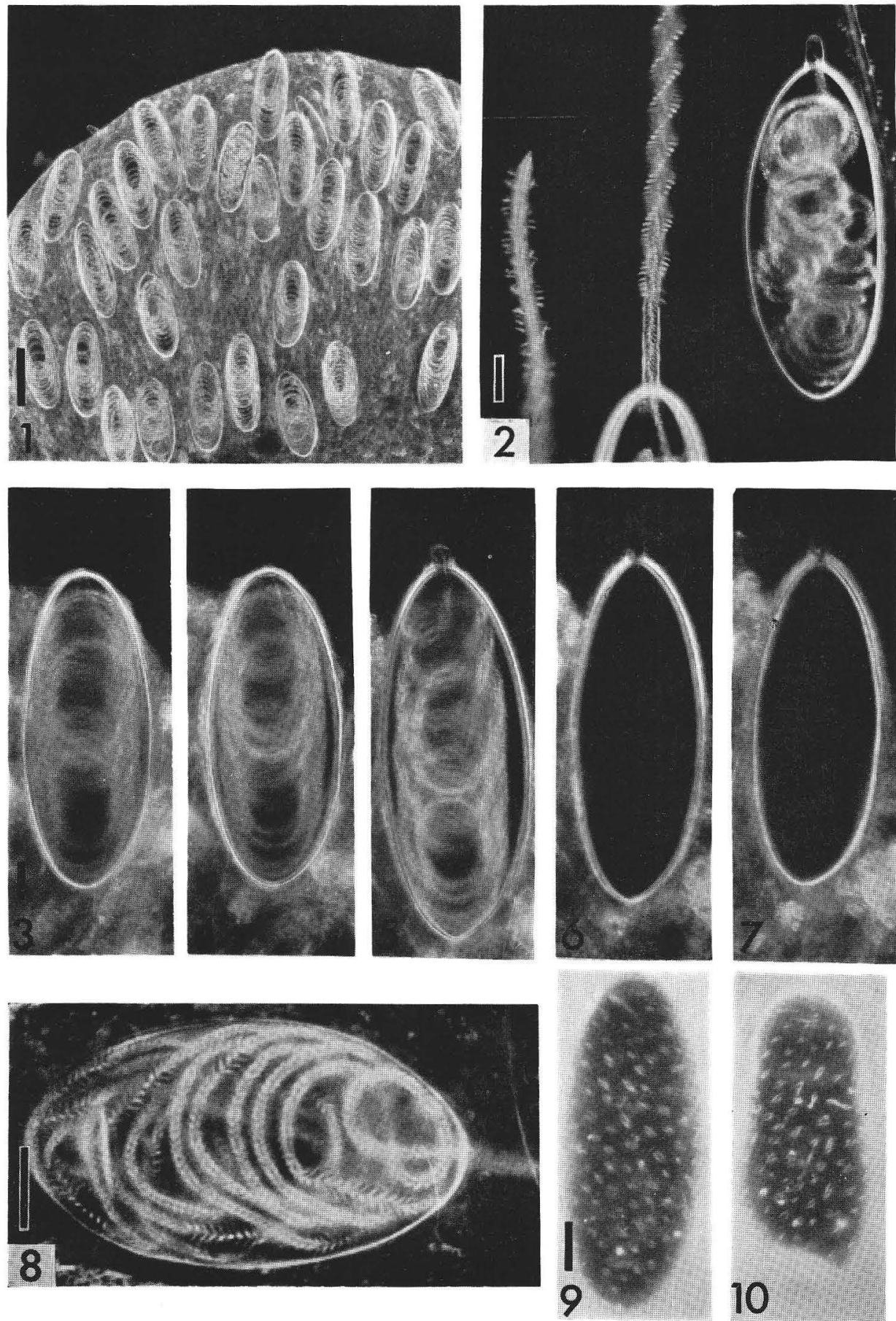

E.A. RoBson: Discharge of Nematocysts and Capsule Properties 
Proc. Second Internat. Symp. Cnidaria

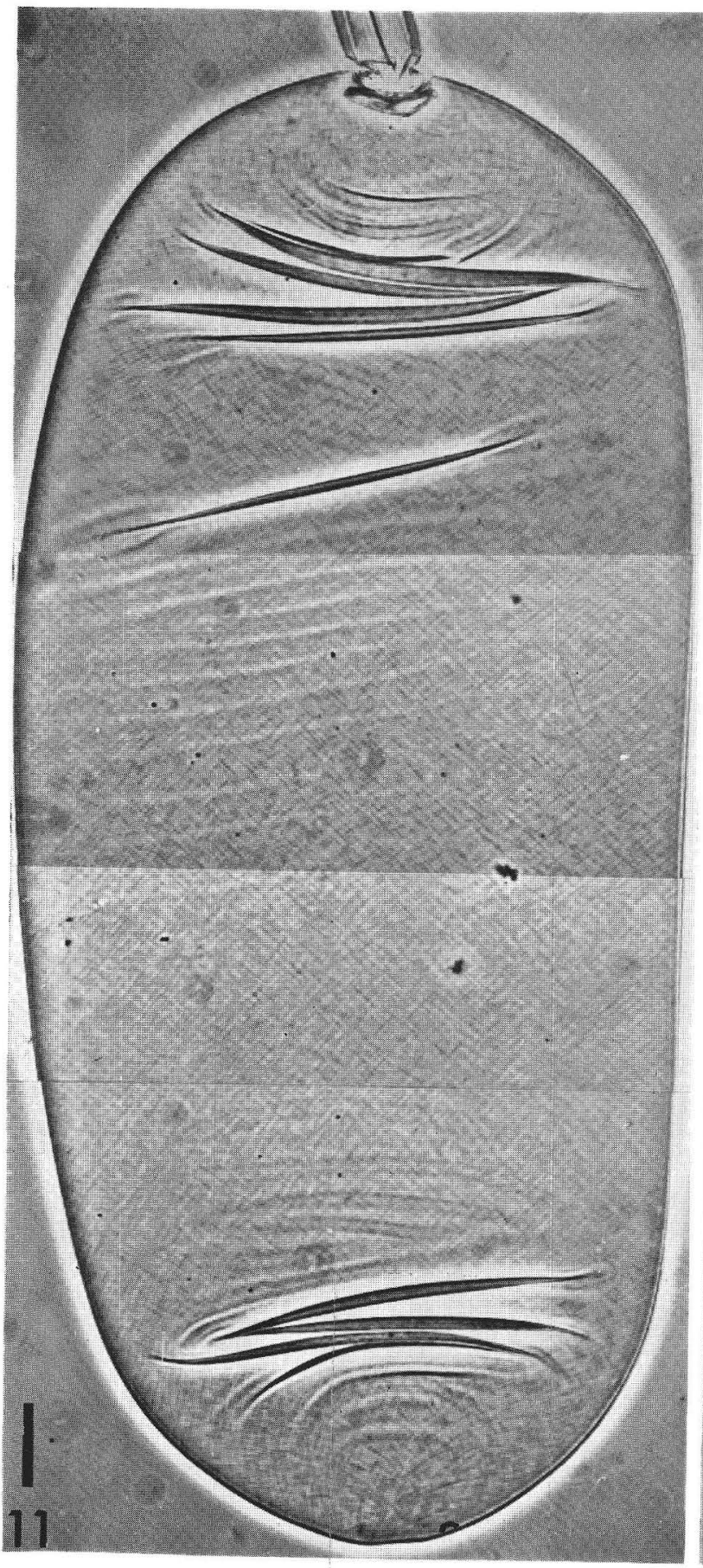

PLATE II
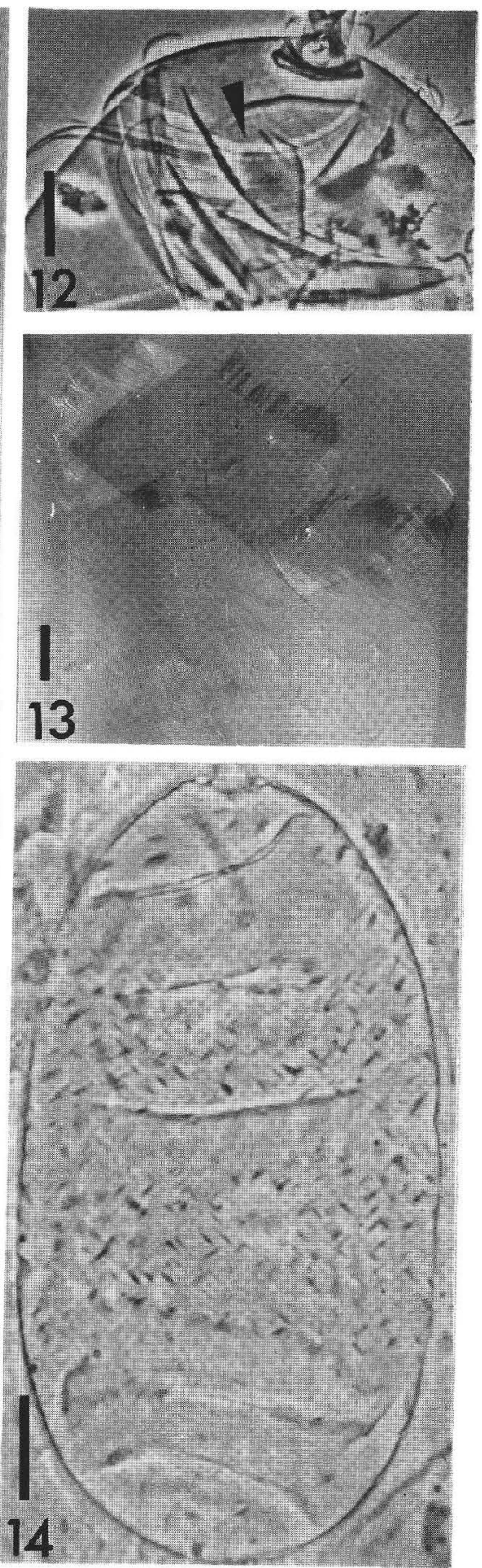

E.A. Roß̉son: Discharge of Nematocysts and Capsule Properties 
Proc. Second Internat. Symp. Cnidaria

PLATE III
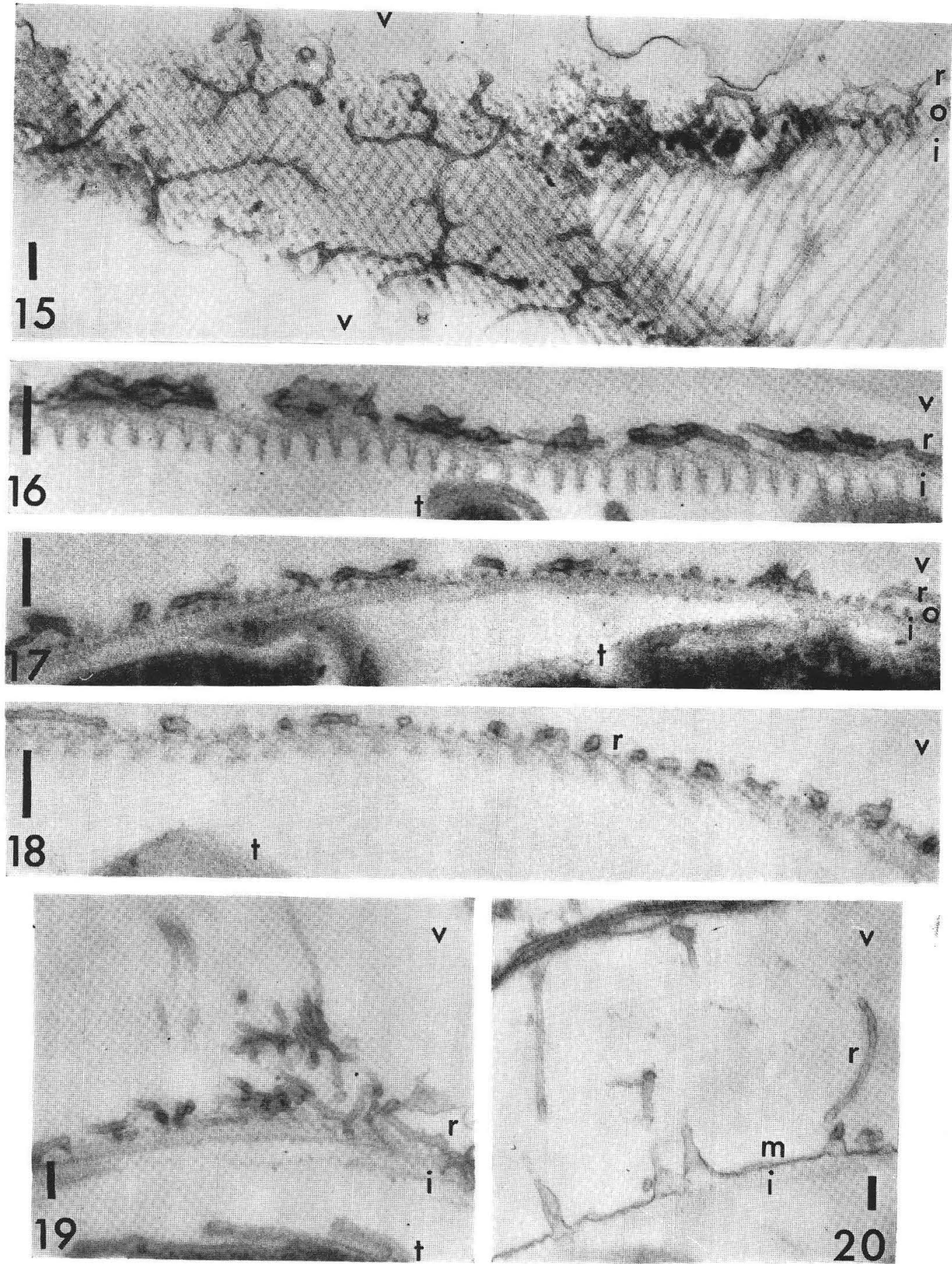

E.A. RoBson: Discharge of Nematocysts and Capsule Properties 
Proc. Second Internat. Symp. Cnidaria
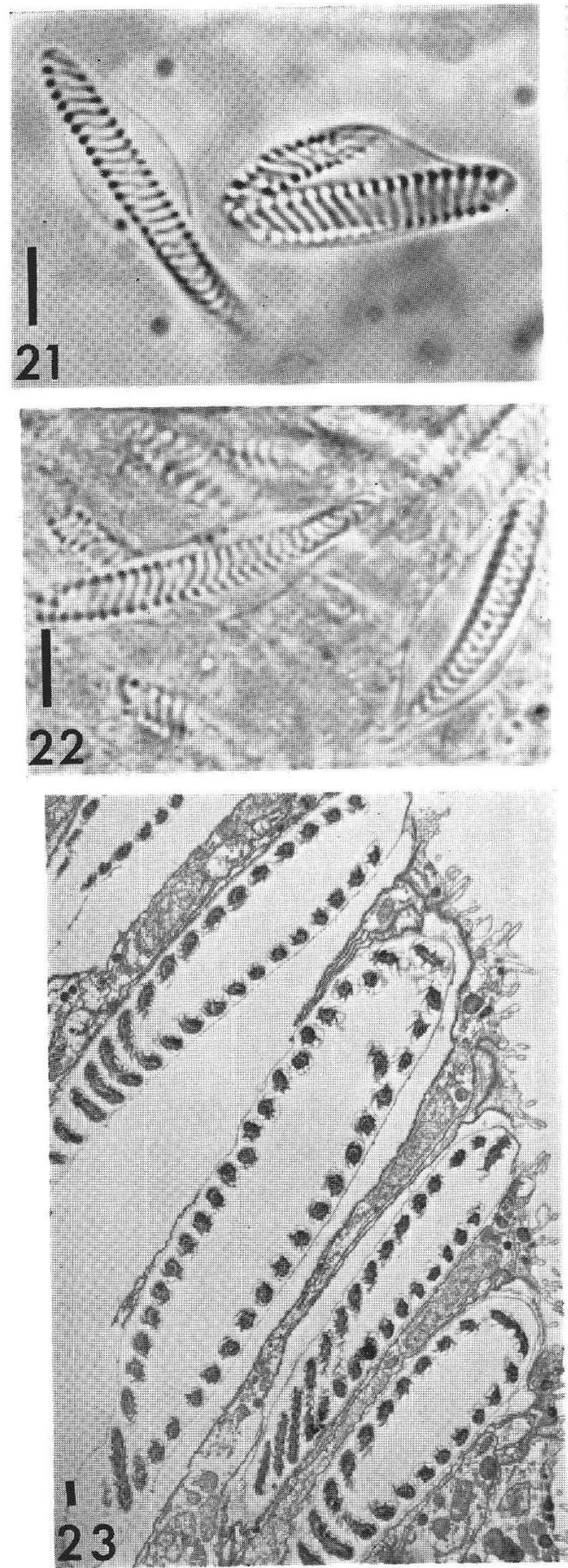

PLATE IV

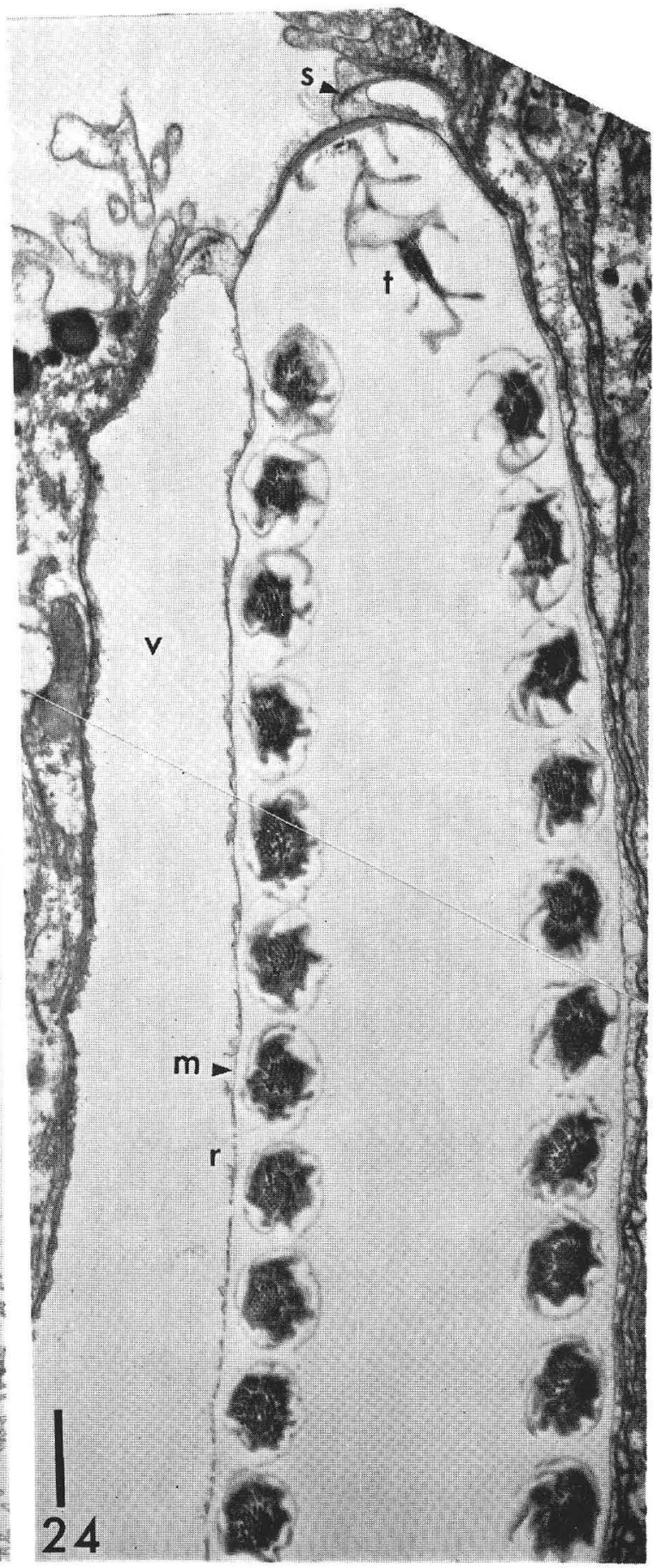

E.A. RoBson: Discharge of Nematocysts and Capsule Properties 
Proc. Second Internat. Symp. Cnidaria

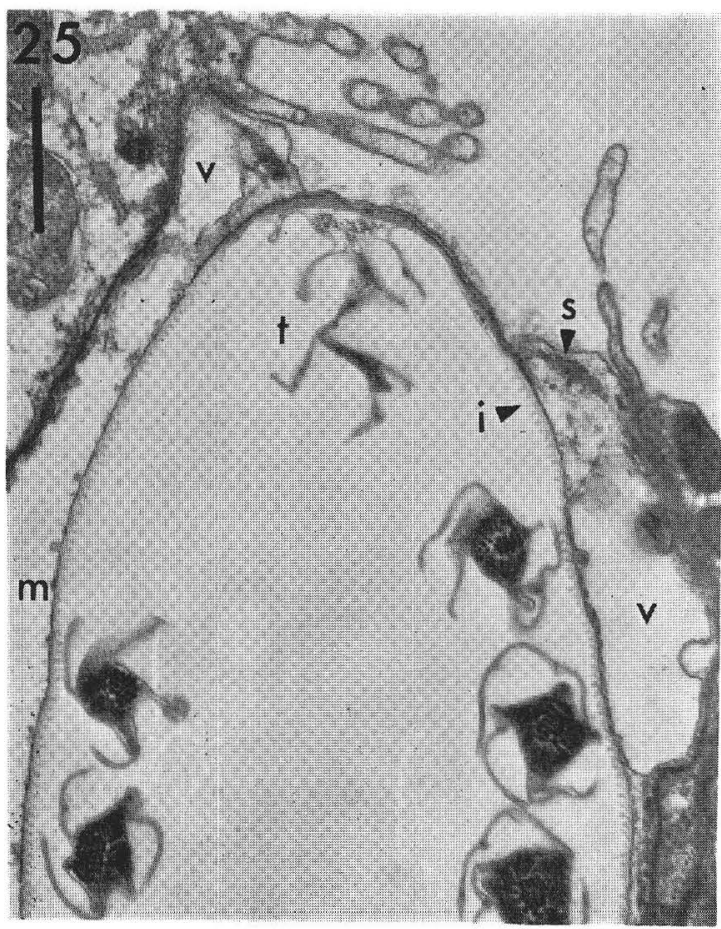

PLATE V

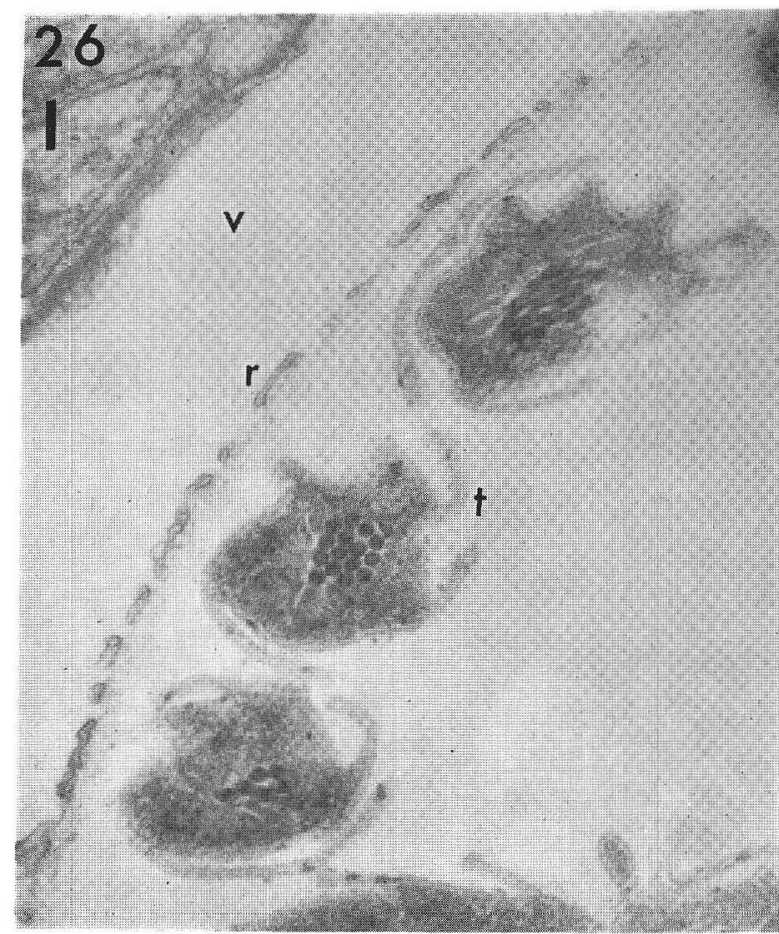

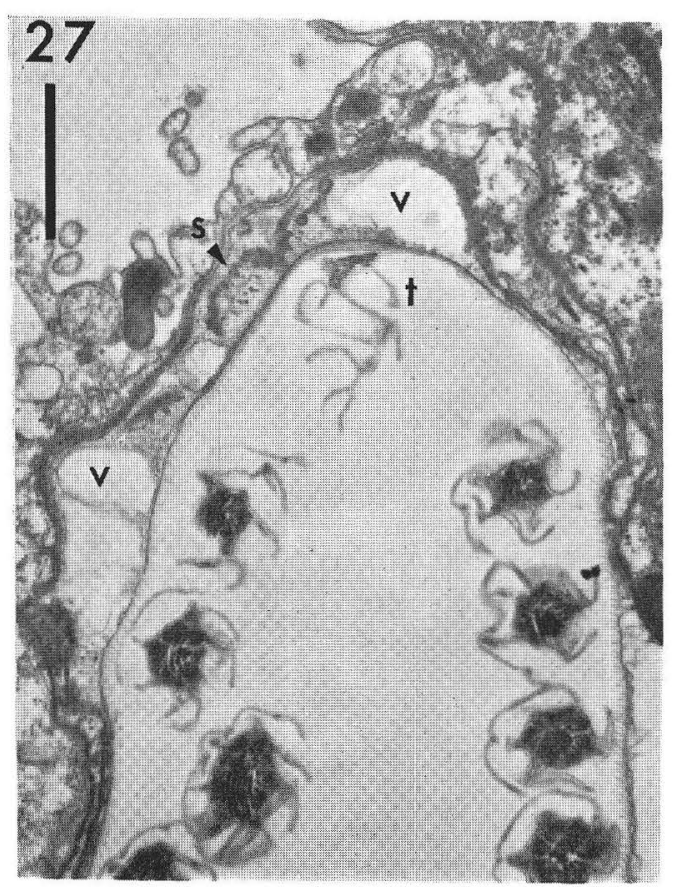

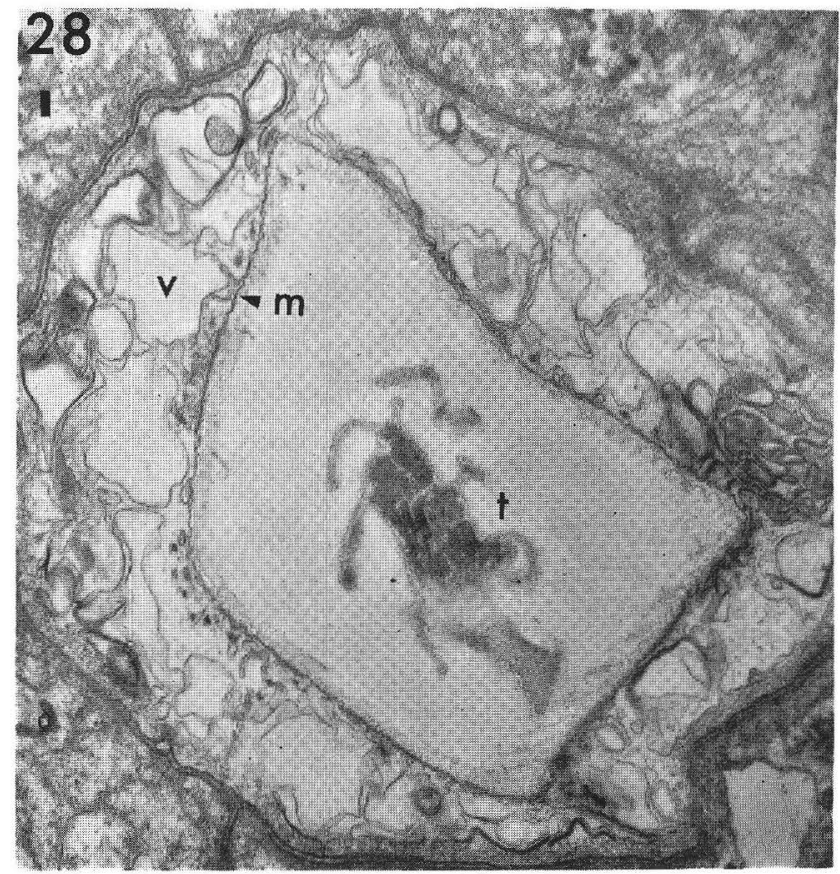

E.A. RoBson: Discharge of Nematocysts and Capsule Properties 